\title{
Sensory Hair Cell Loss
}

National Cancer Institute

\section{Source}

National Cancer Institute. Sensory Hair Cell Loss. NCI Thesaurus. Code C161549.

A finding indicating the loss of sensory hair cells. 